\title{
Extraction of cellulose fibers from flax and hemp: a review
}

\author{
Avinash P. Manian (D) M Michael Cordin (iD) Tung Pham (D)
}

Received: 29 March 2021 / Accepted: 26 June 2021 / Published online: 12 July 2021

(C) The Author(s) 2021

\begin{abstract}
The paper is a review on the extraction processes of cellulosic fibers from flax and hemp. The two lignocellulosic crops have a long history of use by humans for extraction of the bast fibers among other purposes. The utility of bast fibers declined over time with industrial advances and changes to the economy, but of late, with an increase of focus on environmental impact and sustainability, there is a renewed interest in these resources. The use of biomass-based resource requires an appreciation of plant anatomy and the agronomical variables in their cultivation and harvesting. This review provides an overview of these aspects as well as of the processes of retting for initial weakening of the plant structure in preparation for fiber extraction, degumming to isolate fiber bundles, and delignification.
\end{abstract}

The University of Innsbruck Research Institute of Textile Chemistry, Physics is a member of theEuropean Polysaccharide Network of Excellence.

A. P. Manian $(\square) \cdot$ M. Cordin · T. Pham

Research Institute of Textile Chemistry/Physics, University of Innsbruck, 6850 Dornbirn, Austria e-mail: avinash.manian@uibk.ac.at

M. Cordin

e-mail: michael.cordin@uibk.ac.at

T. Pham

e-mail: tung.pham@uibk.ac.at
Keywords Flax $\cdot$ Hemp $\cdot$ Agronomy $\cdot$ Anatomy Retting $\cdot$ Degumming $\cdot$ Delignification $\cdot$ Lignocellulose

\section{Introduction}

Flax (Linum usitatissimum L.) and hemp (Cannabis sativa $L$.) are among the earliest plants cultivated by humans for fibers and extracts from their seeds and flowers. The domestication of flax is believed to have occurred in the Fertile Crescent region (Fu 2011), and the earliest known evidence of flax fiber use, dating to about 30,000 years before the present time, is found in the Republic of Georgia (Kvavadze et al. 2009). Central Asia is believed to be the likely birthplace of domesticated hemp, with the earliest known evidence of hemp fiber use, dating back to about 8,000 BCE, found in Taiwan (Clarke 1999; Tourangeau 2015). Historically, both flax and hemp have been used in the manufacture of fine cloth for apparel as well as heavyduty materials such as sailcloth, canvas cloth, sackcloth, and cordage. Generally, it is easier to produce finer yarns from flax and therefore hemp was often preferred for technical applications (Horne 2012; Kozasowski et al. 2012; Muzyczek 2012; Sponner et al. 2005). Hemp has also been used in the manufacture of paper (Horne 2012). 
The expansion in cultivation and therefore availability of cotton and jute reduced the use of flax and hemp fibers in apparel from about the middle of the eighteenth century, and the advent and increasing availability of synthetic polymers in the twentieth century reduced their use in technical applications (Horne 2012; Salmon-Minotte and Franck 2005). Flax cultivation has continued for linseed oil and other products, but from the 1930s, hemp cultivation suffered from legal restrictions in large parts of the world over fears it will encourage production of the psychoactive substance, delta-9-tetrahydrocannabinol (THC) (Bewley-Taylor et al. 2014; John 2019). However, the recent past has seen a relaxation of regulations in some regions, and even some instances of state subsidies, that has allowed for the emergence of "industrial" hemp cultivation (defined as varieties containing less than a prescribed maximum of THC, generally $0.2 \%-0.3 \% \mathrm{w} / \mathrm{w}$ ) (Horne 2012; Vantreese 2002).

With increasing focus on the use of renewable biomass for the manufacture of materials, there is renewed interest in crops such as flax and hemp (Baley et al. 2020; Baley, 2019; Crini et al. 2020; Ramesh 2019; Sadrmanesh and Chen 2019; Yan et al. 2014). At present, the EU Plant Variety Database lists about 75 varieties of hemp and about 150 varieties of flax that are or may be cultivated in the region (European Commission; European Commission).

\section{Agronomy}

The different varieties of flax can be divided in two broad categories, those suited for fiber production and those for seed production. The fiber varieties are generally taller $(0.8-1.5 \mathrm{~m})$ than the seed varieties $(0.45-0.8 \mathrm{~m})$, and exhibit optimum fiber yields when cultivated in temperate climates with annual rainfall on average of 600-650 mm (Heller, 2015). The seed varieties are more resistant to hotter climates and drought conditions. In relatively cooler climates such as in Europe, fiber flax is planted in the spring (MarchApril) and harvested in summer (July-August) but in warmer regions, the crops are grown over the winter, with planting in late autumn and harvest in late spring (Akin 2010). Fiber varieties are planted at greater densities (2200-2800 plants per $\mathrm{m}^{2}$ ) than seed varieties (1000-1200 plants per $\left.\mathrm{m}^{2}\right)$, as that promotes the growth of thinner, straighter and taller plants leading to better quality fibers (Akin 2010; Heller et al. 2015). Fertilizers (nitrogen, phosphorous, potassium, calcium and magnesium) are required to ensure good crop yields and fiber quality, and measures are needed for weed control and for protection against fungal pathogens and pests. The duration between planting and cultivation ranges between 90-180 days (Nair et al. 2014), as the growth rate and progression through developmental stages varies with both plant variety and ambient temperature - warmer temperatures promote faster development and growth (Carlson 2008). The degree of stem lignification increases with plant development and makes fiber separation from the rest of the stem (retting) progressively difficult, and therefore it is found optimal to harvest plants for fiber extraction during the flowering stage, before seed maturity is attained (Akin 2010, 2013; Meijer et al. 1995). However, that denies farmers potential supplemental income from seed production, which is a motivation for development of "dual-use" varieties yielding both fibers and seeds. An option explored is the cultivation of varieties that exhibit low degrees of lignification even at the seed maturity stage (WrobelKwiatkowska et al. 2007). However, lignin acts to protect plants against pathogens and pests (Liu et al. 2018), and thus the low-lignin flax varieties may be more susceptible to infection from pathogenic fungi such as Fusarium oxysporum (Wrobel-Kwiatkowska et al. 2007).

Hemp plants grow to between 1-6 $\mathrm{m}$ in height depending on the variety and cultivation practices (Fike 2016). It grows optimally in temperate climates where the temperatures range between $15-27{ }^{\circ} \mathrm{C}$, with annual rainfall on average between $630-750 \mathrm{~mm}$ (Adesina et al. 2020). However, hemp is a hardy plant and can be cultivated over a wide range of temperatures and precipitation levels (Dhondt 2020; ŻukGołaszewska and Gołaszewski 2020). It is also shown to be cultivable on degraded land not suitable for other crops due to problems with soil salinity and alkalinity (Zhao et al. 2021). For fiber production, the planting densities vary over a wide range (50-750 plants per $\mathrm{m}^{2}$ ) depending on end use and desired fineness, whereas the densities are lower for seed production ( 30-75 plants per $\mathrm{m}^{2}$ ) (Amaducci and Gusovius 2010; Ranalli 1999). In the open, hemp is planted in springsummer, and the duration of plant development and 
growth is strongly influenced by plant variety and environmental factors (latitude, elevation, air temperature, humidity, soil type) (Campbell et al. 2019; Ranalli 1999). It is also strongly influenced by photoperiodicity, i.e. development is accelerated by periods of short days/long nights (Amaducci et al. 2008; Fike 2016). Fertilization becomes necessary to maintain adequate levels of nitrogen especially if hemp is planted in poorly fertile soils, but as it is a fast growing plant, it can outcompete weeds and thus generally requires low levels of herbicide application (Fike 2016). However, at lower planting densities, when the canopy cover is insufficient to filter sunlight, herbicide use may be required for weed control. The harvesting of plants for fiber production (roughly 70-90 days after sowing) is preferably done at the flowering stage, as further maturation increases the proportion of "secondary" bast fibers in plants, which are shorter in length and more heavily lignified than the primary bast fibers (Amaducci and Gusovius 2010; Fike 2016). Note that secondary fibers do not occur in flax (Gorshkova, 2012). As with flax, work is underway to develop "dual-use" hemp varieties yielding maximal seed and fiber output taking into account variations in geography, climate, water availability, and agronomic practices (Baldini et al. 2020; Fike 2016; Shuvo 2020; Vandepitte et al. 2020). Another alternative is "baby" hemp cultivation, where seeds are planted at high densities in nutrient-rich soil, which encourages rapid growth of plants to acceptable heights without significant accumulation of lignin (Amaducci 2005).

Both flax and hemp may be sown as rotation crops, and it is especially recommended that flax not be grown on the same field more than once in 5-7 years to avoid propagation of fungal infestations in the soil (Heller et al. 2015; Piotrowski and Carus 2011). There is work to show that hemp may be continuously cultivated on the same field for several years without negatively impacting yield (Gorchs et al. 2017). However, planting hemp in rotation with other crops, such as cereals, offers the advantages of improving soil quality, suppressing weed, pest and pathogen infestations, and improving yields (Adesina et al. 2020; Piotrowski and Carus 2011).

\section{Anatomy}

Both flax and hemp are dicotyledonous plants, and as such, exhibit similar anatomies in their stems - from where fibers are extracted. Stem cross-sections exhibit the following entities moving outwards from the center to the periphery: pith, xylem tissue (or woody core), vascular cambium, phloem, cortical parenchyma, epidermis and cuticle (Akin 2010; Chabbert et al. 2013; Goudenhooft et al. 2019; Réquilé et al. 2018a). The "bast" fibers, which constitute the sclerenchyma tissue of the plants, develop in the phloem region as discrete bundles encircling the woody core, and grow in a direction parallel to the vertical axis of the plant. Plant growth is categorized into two types: vertical growth or lengthening of the plant, labelled "primary" growth; and lateral growth or thickening of the plant, labelled "secondary" growth. The growth occurs via division and differentiation of cells from meristematic tissue, and the procambial (or apical) meristem is responsible for primary growth whereas the cambial meristem is responsible for secondary growth.

Bundles of primary bast fibers are formed during primary growth in both flax and hemp. But only in hemp, the cambial meristem produces bundles of secondary bast fibers that begin to appear in plant sections where primary growth has ceased (Amaducci and Gusovius 2010; Chabbert et al. 2013; Mokshina et al. 2018; van Dam and Gorshkova 2003). Thus, primary fibers appear in the early stages of plant development and run through the plant length, while secondary fibers appears in the later stages and are found towards the bottom parts of stems, located in a zone between the woody core and the primary fiber bundles. Fibers also occur in the xylem tissue regions, or the woody cores (termed "shive" and "hurd" in flax and hemp respectively), but they are far shorter, more heavily lignified, and do not occur in bundles (Amaducci and Gusovius 2010; Chernova et al. 2017). The primary and secondary fibers are also termed as the "extraxylary" fibers, since both occur outside xylem tissue regions in the plant, and fibers from the woody cores are termed "xylary" fibers. (Amaducci and Gusovius 2010). Cross-sections of flax and hemp stems showing the primary and secondary fiber bundles, cambium and the xylem tissue, reproduced from literature, are shown in Fig. 1.

The primary fiber bundles, which run along almost the entire length of the plant stem, are constituted by 


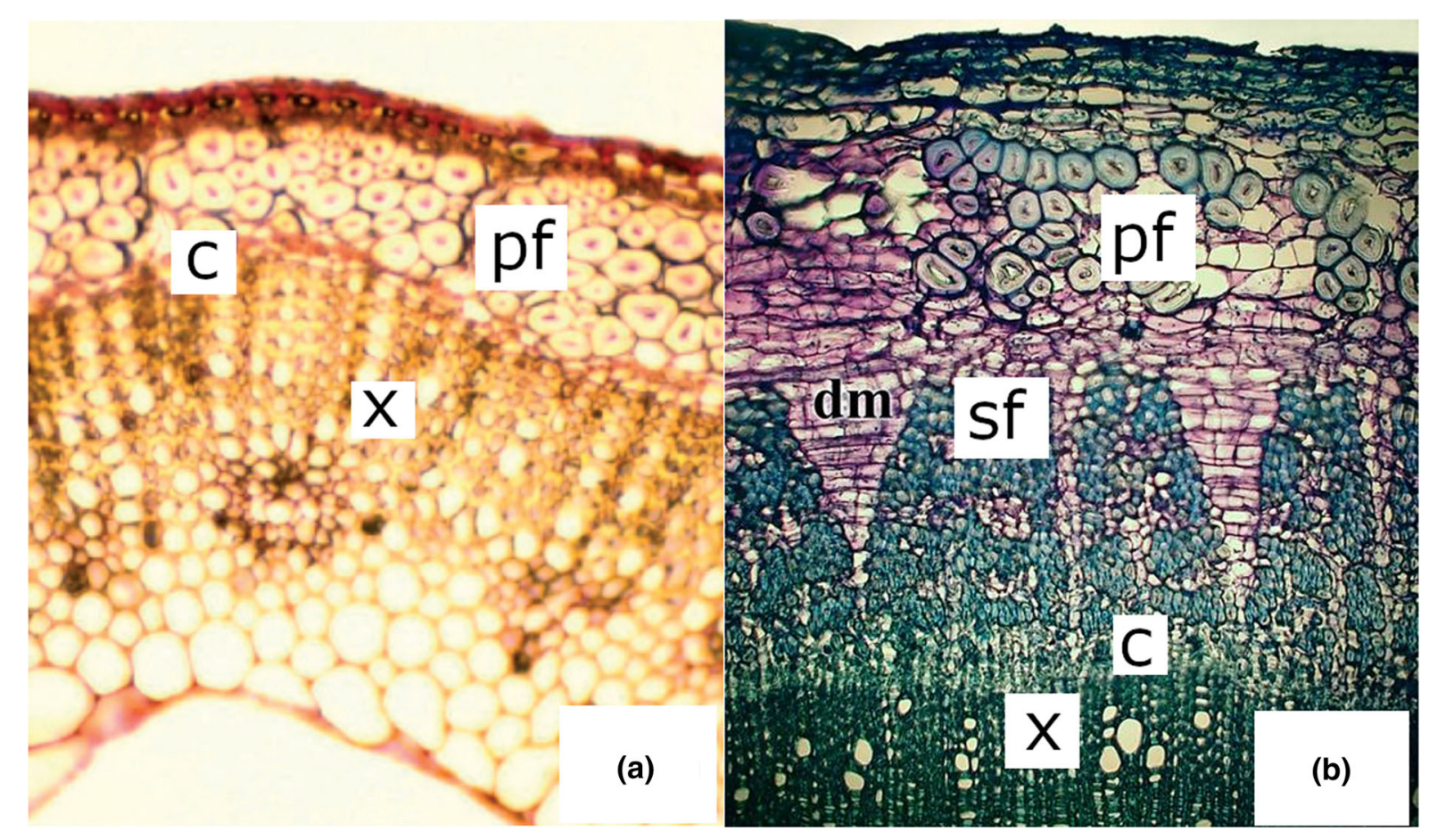

Fig. 1 Cross-sections of flax (A) and hemp (B): "pf" = primary fiber bundles, "sf" = secondary fiber bundles (only in hemp), "c" = cambium, "x" = xylem. Part (A) is reproduced with permission from D.E. Akin, "Plant cell wall aromatics: influence on degradation of biomass". Biofuels, Bioproducts

smaller "elementary" fibers aligned together in an overlapped fashion with a slight twist, such that at any point along the bundle length, a cross-section will reveal about 10-40 elementary fibers (Gorshkova et al. 2012; van Dam and Gorshkova 2003). Primary fiber cells originate on stems at the sites of leaf traces, ${ }^{1}$ and exhibit different stages in their growth and development (Mokshina et al. 2018). The initial growth along the stem axis (i.e. fiber elongation) occurs in tandem with other cells in the surrounding tissues, which is termed "symplastic" or "coordinated" growth (Gorshkova et al. 2018; Goudenhooft et al. 2019). That continues for some hours, until the rate of fiber elongation exceeds that of the surrounding cells, whereupon the fiber cells extend in both directions by pushing through between cells in the surrounding tissues, in what is termed "intrusive growth", which continues for several days. That results in the typical structure of fiber bundles, that of tightly packed overlapping elementary fibers. The degrees of intrusion, and thereby the thickness of fiber bundles, are sensitive to environmental stresses and thus variations and Biorefining 2008, 2, 288-303, John Wiley and Sons. Part (B) is reproduced under Creative Commons CC BY license from A. Snegireva et al., "Intrusive growth of primary and secondary phloem fibres in hemp stem determines fibre-bundle formation and structure". AoB PLANTS 2015, 7, Oxford University Press

in them may be observed along the stem length depending on changing climatic conditions during plant development (Chernova et al. 2017). A schematic illustration of the intrusive growth is shown in Fig. 2.

Secondary fiber cells (which occur only in hemp) are initiated at the cambium, with the first cells appearing approximately halfway along the stem length followed by a progression in cell appearance towards the direction of the root (Chernova et al. 2017). They appear in the course of radial stem growth in sections where elongations have already ceased, and thus secondary fiber cells elongate only through intrusive growth. That, in addition to the presence of lignified mature cells in the surrounding tissues, results in secondary fiber bundles being shorter than the primary fiber bundles.

The fiber cells develop into multi-layered structures in the course of their maturation into elementary fibers. During the elongation phase, the cells consist predominantly of the Primary Cell Wall (PCW) composed of cellulose, pectins and hemicelluloses 


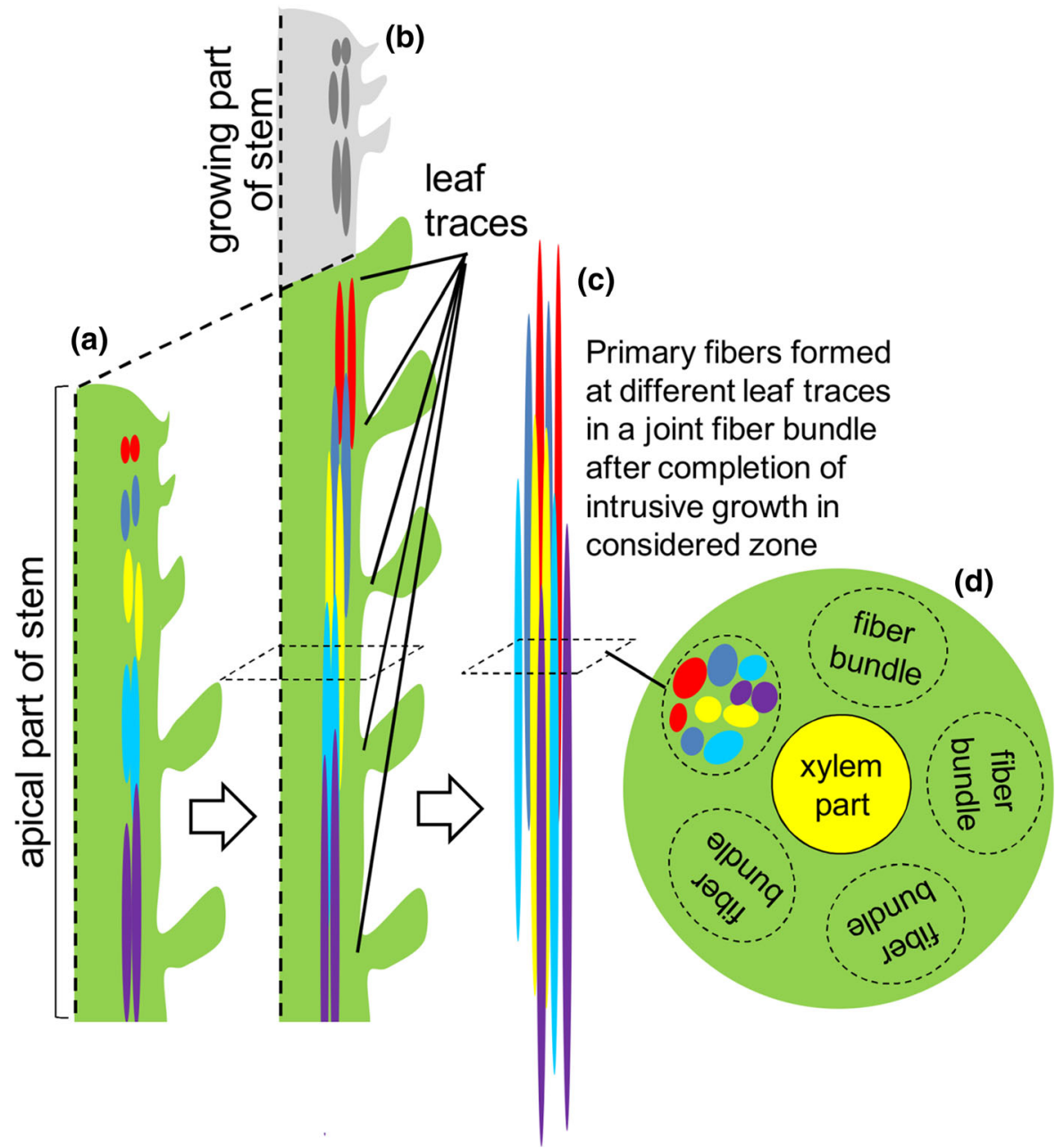

Fig. 2 Schematic illustration of the intrusive growth process. The colored spots in part (a) indicate primary fiber cells, with those initiated at different leaf traces colored differently. The spot sizes represent different stages of development, with small spots representing incipient cells and long streaks more developed cells. Part (b) illustrates the formation of a fiber bundle through elongations of individual fiber cells, and part

(Chabbert et al. 2013; Goudenhooft et al. 2019). The elongation phase is followed by cell thickening, when the Secondary Cell Wall (SCW) is deposited on the insides of the PCW over many weeks. The SCW consists of three layers, labeled S1, S2 and S3 in the direction from the PCW to the lumen at the center. The $\mathrm{S} 1$ is composed of cellulose, hemicelluloses, pectins

\footnotetext{
${ }_{1}^{1}$ Leaf traces are structures connecting the vascular systems of leaves to that of the stem, and serve in the back and forth transport of water, minerals and photosynthesis products. One leaf may be associated with several leaf traces. (Pandey 2005).
}

(c) is a close-up of a fiber bundle. Part (d) is illustrative of a stem cross-section with multiple bundles encircling the woody core. Image reproduced under Creative Commons CC BY license from Mokshina, N.; Chernova, T.; Galinousky, D.; Gorshkov, O.; Gorshkova, T. Key Stages of Fiber Development as Determinants of Bast Fiber Yield and Quality. Fibers 2018, 6, 20. MDPI (Basel, Switzerland)

and lignin, while $\mathrm{S} 2$ and $\mathrm{S} 3$ are composed of cellulose, hemicelluloses and pectins. The S2 and S3 are also referred to as the $\mathrm{G}$ and $\mathrm{Gn}$ layers, and there is an argument for the $\mathrm{G}$ layer to be termed the Tertiary Cell Wall (TCW) but that is under debate (Clair et al. 2018; Gorshkova et al. 2012; Goudenhooft et al. 2019; Mokshina et al. 2018). A schematic illustration of the layers in elementary fibers is shown in Fig. 3.

The cellulose is laid down in the form of microfibrils, which crisscross along the fiber length in the PCW but twist in a helical configuration around the fiber axis 


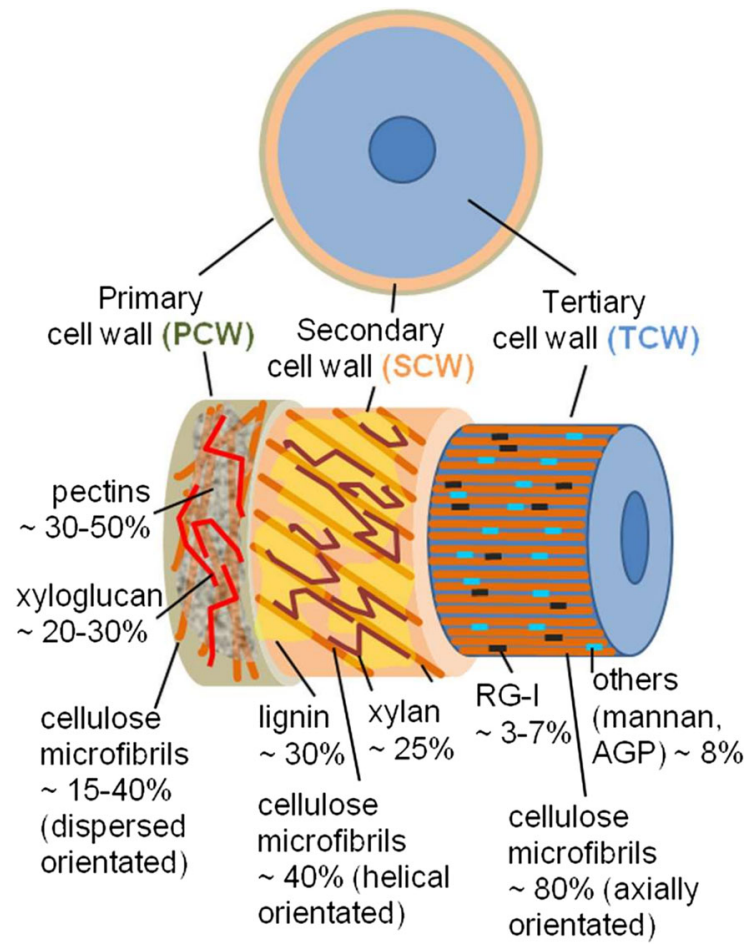

Fig. 3 Schematic illustration of the layers in elementary fibers. Image reproduced under Creative Commons CC BY license from Mokshina, N.; Chernova, T.; Galinousky, D.; Gorshkov, O.; Gorshkova, T. Key Stages of Fiber Development as Determinants of Bast Fiber Yield and Quality. Fibers 2018, 6, 20. MDPI (Basel, Switzerland)

in the SCW layers. Their angle of orientation to the fiber axis (microfibril angle, MFA) differs: in the $\mathrm{PCW}$, it varies over a wide range; in the S1 layer it is in the range of $60-80^{\circ}$ or higher; while in the $S 2$ layer the microfibrils are nearly coaxial to the fiber with MFA of about $8-10^{\circ}$ in flax and about $2.7^{\circ}$ in hemp (Baley et al. 2020; Chernova et al. 2017; Goudenhooft et al. 2019). The $S 3$ layer is essentially nascence of the $S 2$, and often not visible in mature fibers. But when observed, it exhibits a loosely packed, heterogeneous structure. In primary fibers, the S2 layer constitutes the major proportion of the fiber bulk with the PCW and S1 layers constituting minor proportions.

The interaction forces between elementary fibers in a bundle exceed that between the bundle and its surroundings, which is attributed to (Chabbert et al. 2013; Gorshkova et al. 2012; Rognes et al. 2000):

- The shape of individual elementary fibers (narrow and elongated) promotes better interaction between them as compared with smaller, rounded shapes of other cells in the surrounding tissue;

- Tight packing between the elementary fibers due to the intrusive mode of their growth and elongation; and,

- The middle lamella (interface between elementary fibers) contains low-methylated, highlybranched pectins allowing for strong calcium pectate gels, and deposits of phenolics including lignin.

The proportions and compositions of the main components (cellulose, pectins, hemicelluloses and lignin) vary between the different cell wall layers in elementary fibers, between primary elementary fibers from hemp and flax, and between primary and secondary elementary fibers in hemp (Chernova et al. 2018; Goudenhooft et al. 2019; Mokshina et al. 2018). A comparison of the overall features of primary fiber bundles from flax and hemp, in terms of their dimensions and chemical composition is shown in Table 1. The bundle lengths are longer in hemp compared to flax due to the differences in plant height. The lengths of elementary fibers are similar in both but their widths in hemp are larger than in flax. Hemp primary bundles contain marginally higher proportions of lignin and also contain parenchyma cells, which is not observed in flax. Further, the hemp primary bundles frequently split and merge with adjacent bundles along the stem, but that does not happen in flax where the bundles maintain unity along the entire stem length (Snegireva et al. 2015). Table 1 also shows that xylary fibers (i.e. fibers from shives and hurds) do not form bundles, are far shorter than elementary fibers in primary bundles, and are significantly more lignified.

\section{Retting}

The extraction of fibers from harvested flax and hemp stems begins with "retting" for an initial weakening of interactions between the fiber bundles and the woody core and surrounding tissue (i.e. initial loosening of the stem structure). That is followed by mechanical processes to separate the fiber bundles. The mechanical processes may be broadly classified into the following three steps (Salmon-Minotte and Franck 2005; Sponner et al. 2005). 
Table 1 Range of physical dimensions and representative chemical composition of primary bast fibers and xylary fibers of flax and hemp (van Dam and Gorshkova 2003)

\begin{tabular}{|c|c|c|c|c|c|c|c|}
\hline & \multicolumn{3}{|l|}{ Dimensions } & \multicolumn{4}{|c|}{ Chemical composition $^{a}$} \\
\hline & \multirow[t]{2}{*}{ Bundle length $(\mathrm{cm})$} & \multicolumn{2}{|c|}{ Elementary fibers } & \multirow[t]{2}{*}{ Cellulose $(\%)$} & \multirow[t]{2}{*}{ Pectins $(\%)$} & \multirow[t]{2}{*}{ Hemicelluloses (\%) } & \multirow[t]{2}{*}{ Lignin $(\%)$} \\
\hline & & length (mm) & width $(\mu \mathrm{m})$ & & & & \\
\hline \multicolumn{8}{|l|}{ Flax } \\
\hline Primary bundles & $30-90$ & $13-60$ & $12-30$ & 75 & 3 & 15 & $<1$ \\
\hline Shives & - & $0.1-0.5$ & $10-30$ & 37 & 3 & 25 & 30 \\
\hline \multicolumn{8}{|l|}{ Нетр } \\
\hline Primary bundles & $100-300$ & $5-55$ & $16-50$ & 70 & 3 & 15 & 3 \\
\hline Hurds & - & $0.5-0.6$ & $15-40$ & 40 & 3 & 25 & 25 \\
\hline
\end{tabular}

${ }^{a}$ Note that the chemical composition of fibers and bundles differ between varieties, agronomical variables, stem sections, and extraction processes - hence, the values listed here are only representative

Breaking: To break up the woody core (i.e. shives or hurds), which is achieved by crushing plant stems through pairs of fluted rolls.

Scutching: To remove the broken pieces of woody core as well as short fibers, which is achieved by passing the broken stems through pairs of rotating blades that strike and beat out the undesired material.

Hackling: To parallelize scutched fiber bundles and further remove pieces of woody core and short fibers, which is achieved by pulling the bundles through comb-like structures.

The end-product after hackling consists predominantly of individual fiber bundles, with some split into finer strands, i.e. elementary fibers. As such, this material may be used in technical applications, e.g. for cordage, composites and industrial fabrics. For construction of fine apparel, the hackled fibers generally need to be subjected to further chemical processing to separate the majority of bundles into finer, more uniform strands. Of the remaining plant mass, short fiber bundles of acceptable lengths may be used for yarn spinning, and the rest has traditionally been used as animal litter, heat insulation material, fuel, or natural fertilizer.

Retting may be achieved by traditional processes (field/dew or water), or through industrial technologies as described below.

\section{Field (or dew) retting}

Flax plants are pulled and hemp plants are cut at harvest, and laid out in oriented piles on the field (swathing or windrowing) (Desanlis et al. 2013; Horne 2012; Salmon-Minotte and Franck 2005). The pile heights and densities are maintained at levels that allow for good air circulation, and are 'turned' at regular intervals to ensure that all material is equally exposed to elements of the weather. Soil microorganisms populate the resting plants and metabolize their soft tissues, making it easier to separate the fiber bundles. With time, even the fiber bundles begin to be metabolized which reduces fiber quality, and therefore the plant mass needs to be removed from the field and processed at the optimal time. That sufficient levels of retting have been achieved is judged from changes in color of the plant material and by manually testing the ease of separating the woody core from the bark material. Machinery for mechanized harvesting and turning of flax is available commercially, but the hiatus in hemp cultivation has meant that older machinery is put back into use or machinery designed for other crops is repurposed, but manufacturers are beginning to develop new designs specifically for hemp (Desanlis et al. 2013; Gusovius et al. 2016; Salmon-Minotte and Franck 2005).

Both fungi and bacteria are active in field retting, and the degradation is reported to proceed in almost a sequential manner (Fernando et al. 2019; Liu et al. 2017). The first microorganisms to colonize the harvested mass are found to be fungal species, which are able to breach the cuticular layer with extracellular cutinases as well as by hyphal entry through damaged areas. That is followed by bacterial species that take advantage of the ingress points into the plant structure, and together with fungal species, metabolize 
parenchyma cells between fiber bundles with pectinolytic enzymes and hemicellulases. The bacteria appear to colonize areas in close vicinity to fungal hyphal structures, utilizing them as "highways" into the plant. At later stages, there is an increase of microbial populations producing cellulolytic enzymes, which are responsible for damage to the cellulosic cell walls of bast fiber bundles observed in prolonged periods of retting. The fungal species most active in the retting process are found to be from the Ascomycota and Basidiomycota phyla, and bacterial species from the Proteobacteria, Actinobacteria and Bacteroidetes phyla, with the proportions of individual species varying with soil type and time of the year (Ribeiro, 2015). Cells with greater lignin content are less susceptible to microbial degradation, and that is one possible reason for the woody core to degrade at a much slower rate than the cortical region, but it is also thought possible that the architecture of the xylem tissue acts to limit microbial propagation through the structure (Chabbert 2020).

The advantages of field retting are that the residues may serve to enrich the soil, process costs are low, and problems of malodor are avoided (Adesina et al. 2020; Akin 2013). The disadvantages are that the fields remain unavailable for sowing of fresh crops, and it is difficult to control fiber yield and quality as the retting process is highly dependent on the weather as well as geography (Placet et al. 2017). Some alternatives that have been explored to limit influence of the weather include utilizing spring frosts to aid in the separation of fiber bundles due to formation of extracellular ice crystals in the plant (Pasila 2000), and ensiling of harvested plants to allow anaerobic retting although care is required to prevent mold growth (Gusovius et al. 2019; Martin et al. 2013).

\section{Stand retting}

Also termed as pre-harvest retting, this is a variant of field retting, where the operating principle is to spray standing crop with a herbicide-formulations of glyphosate ( $\mathrm{N}$-(phosphonomethyl)glycine) are commonly employed-which then permeates through the plant via the phloem tissues (translocation) causing death and desiccation of the plants (Shekhar Sharma et al. 1989). Microbial populations are then able to colonize and degrade the plant soft tissues (similar to field retting), and aid in separation of the fiber bundles.
The advantage is that stand retting does not require swathing and turning, and the plants after retting may directly be harvested and transported for further processing. Alternatives to the spraying of herbicides include the use of open flames to terminate plant growth or allow the plants to die naturally (Assirelli et al. 2020; Ramesh 2018).

Key variables for success of this strategy is to time the spraying at the optimal growth stage of the plant, which is found to be about the mid-point of flowering (Sampaio et al. 2005). If the spraying is performed earlier, then higher proportions of immature fibers are found in the harvested plants; and if the spraying is later, then the herbicide may not be uniformly translocated and therefore the desiccation and retting levels are also non-uniform (Harwood et al. 2008; Shekhar Sharma et al. 1989). Not all varieties may yield the same response to herbicide spraying, and translocation efficacies decrease with elevation of water stress, i.e. the plants require sufficient watering for optimal results (Easson and Cooper 2002; Harvey and Crothers 1988; Harvey et al. 1985). In addition, the challenges of weather-related influence on retting progress and efficiency, as well as the field being unavailable for sowing of other crops, also apply to stand-retting.

\section{Water retting}

It describes the process where harvested plants are immersed in natural or artificial water bodies (e.g. streams or tanks respectively) to allow for microbial degradation of plant soft tissues. The retting is initiated by aerobic bacteria (from the Bacillus or Paenibacillus genus), and on exhaustion of available air, continued by anaerobic bacteria (from the Clostridium genus) (Di Candilo et al. 2010; Tamburini et al. 2004, 2003). The duration required for adequate retting under water (1-2 weeks) is shorter than on the field (5-6 weeks), the influence of weather and geography is minimized; and variables such as temperature and $\mathrm{pH}$ levels can be maintained at optimal levels in artificial water bodies (Magnusson and Svennerstedt 2007). Despite these advantages, and the general observation that water retting yields finer and stronger fibers, water retting has fallen from favor in Western Europe due to the costs of drying wet fiber bundles and treating the wastewater, and problems of 
malodor in the retted products (Akin 2013; Jankauskiene et al. 2015; Liu et al. 2017; Morrison 2000; Morrison et al. 2000).

There are challenges with field, stand and water retting in the decision making of when to cease the process and transport the biomass to the next stage of processing. It is important to achieve control over the degree of retting, since if the plant material is retted overlong; the cellulose begins to be degraded. In field retting, attempts have been made to define "standard" days that normalize retting durations with respect to average daily temperatures and humidity (Réquilé, 2021). However, the calculation of standard days does not account for variations in precipitation levels, soil drainage and strength of solar radiation, all of which influence the rate of microbial growth and propagation, which limits the use of this approach. However, advances in microbiological and biochemical sciences, namely in metagenomics, metatransciptomics and metaproteomics, are making it possible to investigate and analyze these correlations to improve understanding and thereby achieve greater control over the retting process (Djemiel et al. 2020). Other attempts to chart the course of retting and obtain consistent results, include measurements of color change in the plant mass, measuring the emanation of volatile organic compounds and odor, analyzing changes in chemical composition, or subjecting the plant mass to standardized peeling tests (Bleuze et al. 2020; Mazian et al. 2019; Mooney et al. 2001; Réquilé et al. 2018b). Nonetheless, the practice commonly followed at present is for farmers to empirically judge the adequacy of retting by sight, touch, and smell.

\section{Industrial processes}

The challenges with field and water retting have prompted investigations on developing industrial processes to produce consistent and good quality fiber bundles. The aim of such processes is often not limited only to isolating the fiber bundles, but also to divide them into finer strands. That requires removal of the cementitious material from the middle lamella (i.e. interface between elementary fibers), which is termed "degumming". When it proceeds to the extent that individual elementary fibers may be extracted, the process is termed "cottonization" ${ }^{2}$ (Waldron and
Harwood 2010). There are primarily three treatment modes: chemical, microbial and enzymatic.

Enzymatic treatments

The raw material for enzymatic treatment may be whole stems, bark material stripped from the woody core, or "decorticated" material obtained after a brief retting (field/water) followed by mechanical processes to separate out the woody core (De Prez et al. 2019b; Juarez et al. 2013; Liu et al. 2016). In treatments of whole stems, a prior disruption of the plant structure is found necessary to allow enzyme liquors access to the soft tissues, examples of which are hydrothermal pretreatment or mechanical crimping (Akin et al. 2004; Liu et al. 2016). Other process considerations include the ratio of enzyme liquor to plant material $(\mathrm{kg}$ liquor / $\mathrm{kg}$ plant material) as that dictates material and energy requirements and therefore process costs (Akin et al. 2000).

The natural process of retting in the field and in water occurs through microbial populations utilizing pectinases, hemicellulases and cellulases, and thus in principle, enzymatic formulations should contain the same components (Akin 2013; De et al. 2018); but in practice, it is found that pectinases are key. Polygalacturonases target the low-methylated pectins in the middle lamella region, and it appears that hydrolysis of these components is of primary importance for a satisfactory separation of fiber bundles (Akin et al. 2004; Zhang et al. 2000). The pectins are crosslinked with $\mathrm{Ca}^{2+}$ ions, and therefore the use of chelators during the enzymatic process or in a pre- or posttreatment step is found to significantly improve separation efficiency (Akin 2013; De et al. 2018). Ethylenediaminetetraacetic acid (EDTA) is commonly employed as chelator since the enzymes operate in a mildly acidic range ( $\mathrm{pH} 4-6)$, and most other chelators exhibit maximum complexation ability in alkaline $\mathrm{pH}$ (Adamsen et al. 2002a; Akin et al. 2002, 2004; Chabbert et al. 2020; De Prez et al. 2019b). The type of polygalacturonase has an influence, as the enzyme extracted from different

\footnotetext{
${ }^{2}$ Note that cottonization only denotes refining the long, coarse bast fiber bundles into dimensions (length and fineness) that allow for blending with cotton. That may be achieved only through mechanical forces, but that risks damage to the fiber and greater proportions of fiber waste.
} 
microorganisms do not exhibit the same efficiencies (Evans et al. 2002). An alternative is the use of pectin or pectate lyases which operate optimally in the alkaline range ( $\mathrm{pH} 7-11)$ (Bonnin et al. 2009), as that suppresses the activities of other components found in enzyme formulations such as cellobiohydrolases, and improves quality of the extracted fiber bundles (Akin et al. 2007; Alix et al. 2012; De Prez et al. 2019a).

Investigations on enzymatic retting reported in literature focus predominantly on flax, and it is found that the developed treatment protocols may not yield similar results on hemp (Akin 2013; Fischer et al. 2006). It is also the case that despite promising results and commercial-scale availability of enzymatic retting formulations, there is a lack of industrial-scale implementation of processes, attributed to a combination of factors including the process costs (Akin 2013).

\section{Microbial treatments}

These treatments involve the inoculation and incubation of microbial cultures on plant material (decorticated material, stripped bark or crushed stems) at optimal $\mathrm{pH}$ and temperatures for requisite durations, on plants submersed in liquid tanks or on damp plant material in sealed plastic bags. Such investigations have been performed both with bacterial cultures (e.g. Clostridium felsineum, Clostridium acetobutylicum, Geobacillus thermoglucosidasius) and with fungal cultures (e.g. Schizophyllum commune, Rhizomucor pusillus, Fusarium lateritium, Epicoccum nigrum) (Akin et al. 1998; Di Candilo et al. 2000; Donaghy et al. 1992; Henriksson et al. 1997; Juarez et al. 2013; Li et al. 2009; Liu et al. 2017). However, such treatments suffer from the disadvantages that the processes take long and are difficult to control, and some microbial strains may be pathogenic (Akin et al. 1998; De et al. 2018).

\section{Chemical treatments}

Chemical treatments offer the advantages of being more rapid and less expensive than enzymatic processes, but often yield more coarse fibers. A common approach is to treat flax stems with solutions of complexing agents and detergents buffered to high $\mathrm{pH}$ (10-11) with alkali. Examples of complexing agents include EDTA, diethylenetriaminepentaacetic acid, oxalic acid, tetrasodium pyrophosphate and sodium tripolyphosphate; the alkalis commonly employed are $\mathrm{NaOH}, \mathrm{KOH}$ or $\mathrm{Na}_{2} \mathrm{CO}_{3}$; and sodium dodecyl sulfate (SDS) is widely used as detergent (Adamsen et al. 2002b; Beltran et al. 2002; Henriksson et al. 1998; Keller et al. 2001; Rognes et al. 2000; Sharma 1988). Such formulations have also been investigated as impregnation media for steam explosion processes, where the treated stems are subject to steam under high pressure followed by a rapid decompression (GarciaJaldon et al. 1998; Kessler et al. 1998; Vignon et al. 1996). Treatments of harvested flax with sulfur dioxide aid in preservation of moist plant material for longer durations and increase the retting rate in subsequent enzymatic treatments, but the resulting fiber bundles are coarse and prone to contain residues of inorganic salts (Easson et al. 1998; Sharma et al. 1999). Spraying of urea and EDTA after glyphosate application increases rates in stand retting (Sharma 1986).

Physical treatments

Polar molecules interact with oscillating microwave and radio frequency radiation by undergoing rapid rotations, which generates thermal energy (termed dielectric heating) in proportion to the level of interaction. That enables a degree of selectivity as pectin is more polar than cellulose and thus heats up and is degraded at greater rates (Gregoire et al. 2019; Nair et al. 2015). Physical separations of the pectin from the cellulose are also likely. Presoaking of the harvested stalks in water is found to improve pectin removal efficiency, attributed to the plasticization of pectin (Nair et al. 2014; Ruan et al. 2020a, b). The processes are envisaged either as stand-alone treatments or as pretreatments for a subsequent enzymatic or chemical process of retting, but it is to be noted that the wastewater may present the same challenges as those from water retting (Zhao et al. 2020).

\section{No retting}

It is possible to separate the plant mass into fine strands without retting purely by mechanical forces, but that increases the propensity for inducing structural defects in fibers. They are termed "kink" bands, which are often the locus of failure under stress, and arise from disruptions to cellulose chain alignments in fiber 
structures (Akin 2010, 2013; Haenninen et al. 2012). Nevertheless, it has been demonstrated that composites of equal performance may be obtained with either retted or unretted fibers (Hepworth et al. 2000; Sisti et al. 2016). However, the presence of pectic substances and hemicelluloses in unretted plant material contributes significantly to moisture absorption propensities of the biomass, which can lead to fiber swelling/deswelling induced delamination as well as increased susceptibility to fungal attack - and limits the durability of composites (Kymalainen et al. 2004; Liu et al. 2017; Pott 2002). Thus, the retting process has an impact on durability, in addition to immediate mechanical performance.

The sensitivity to moisture sorption may be reduced by chemical treatments such as acetylation, or a hydrothermal process termed the "Duralin" process, where harvested stalks are autoclaved at temperatures in excess of $160{ }^{\circ} \mathrm{C}$, dried and subjected to dry heat at temperatures above $150{ }^{\circ} \mathrm{C}$. (Dijon et al. 2002; Stamboulis et al. 2001). It serves to depolymerize hemicellulases and lignin, which then condense to form a waterproof resin coating on fiber bundles and improve their mechanical properties.

\section{Delignification}

The amount of lignin in fiber bundles of both flax and hemp is low (see Table 1), but due to its localization in the middle lamella, delignification treatments contribute significantly to cottonization, i.e. separating fiber bundles into their constituent elementary fibers (Akin 2013; Henglein 1969; Kiyoto et al. 2018; Rahman and Sayed-Esfahani 1979). Delignification of the woody core (i.e. shives and hurds) is also of interest to obtain fibers for the pulp and paper industry. As with retting, investigations on industrial processes of delignification have focused primarily on enzymatic, microbial and chemical modes of treatment.

\section{Enzymatic treatments}

Lignin is susceptible to the oxidative enzymes manganese peroxidases, lignin peroxidases and laccases, but laccase systems have most commonly been investigated for enzymatic delignification treatments (Fillat et al. 2010). The use of laccases alone yields limited results, as the delignification proceeds through heterogeneous redox reactions, and the enzymes often have limited access within substrate structures. Therefore, smaller molecules are employed as mediators. The principle is that mediator molecules are oxidized by the enzyme, diffuse through the substrate structure to oxidize lignin and other aromatic structures, become reduced in that process, and thus are available to repeat the cycle (Christopher et al. 2014). Mediators also enable the oxidation of non-phenolic units of lignin, which cannot be achieved with laccases alone due to their low redox potential $(0.5-0.8 \mathrm{~V})$. Both synthetic molecules (e.g. 1-hydroxybenzotriazole, violuric acid) and naturally occurring compounds (e.g. syringaldehyde, acetosyringone, p-coumaric acid) have been investigated as mediators, and the most effective are found to be N-hydroxy compounds, i.e. those that contain a-N(OH) - group (Camarero, 2004; Fillat et al. 2010, 2011, 2012; Fillat and Blanca Roncero 2009; Fillat and Roncero 2009a, b). An alternative is to employ hemicellulases, as the lignin exists in complexes with xylans and mannans, and thus the destruction of these complexes releases the lignin (Cheshkova et al. 2013).

Microbial treatments

White-rot fungi, e.g. from the Bjerkandera and Phanerochaete genus, have been widely investigated for delignification treatments, as they degrade lignin at higher rates compared to other plant components (e.g. cellulose) (Dorado et al. 2001a). That selectivity for lignin degradation may be further improved by reducing nitrogen levels (or increasing the carbon-to-nitrogen ratio) in substrates, for example through pretreatment with protease enzymes (Dorado et al. 2001b; Huang et al. 2020). Other fungi investigated for delignification treatments include Ceriporiopsis subvermispora, which lack cellulases and thus exhibit inherent lignolytic selectivity (Akin 2008).

\section{Chemical treatments}

Many chemical treatments investigated for flax and hemp delignification derive from pulping processes and include the kraft, soda and sulfite methods (Correia et al. 2001; de Groot et al. 1995; Mustata 1994; Petrova et al. 2004). Bleaching operations common in pulping processes have also been investigated, with sodium chlorite (Pacaphol and Aht-Ong 2017), oxygen 
(Danielewicz and Surma-Slusarska 2011; Kopania et al. 2012), hydrogen peroxide (Kopania et al. 2012; Pandey et al. 2019; Petrova et al. 2003), peracetic acid (Danielewicz and Surma-Slusarska 2011) and oxone (Stewart and Morrison 1996). Other investigations have looked at treatments with formic acid (de Vega and Ligero 2017), nitric acid (Shishonok and Shadrina 2006), ethanol/water mixtures (Gosselink et al. 1995), and ionic liquids ( $\mathrm{Fu}$ et al. 2010). With a view to develop treatments that are more lignin-selective and generate lower chemical loads in the process wastewater, investigations have been performed on the use of hydrotropic reagents (Denisova et al. 2015) and with pressurized low polarity water (Kim and Mazza 2009).

\section{Physical treatments}

In investigations on air plasma treatments for delignification, a direct exposure of retted stalks to plasma discharge is found less effective as the process cannot be sufficiently controlled to prevent cellulose from being damaged. Indeed, the primary impact of direct treatments is seen to be the formation of significant cracks and cavities and a general roughening of fiber surfaces (Baley et al. 2019; Pejić et al. 2020). Indirect treatments are found more effective, where fiber bundles are immersed in mildly acidic or alkaline media and a plasma discharge is directed into the liquid close to the bundles or at air bubbled through the system (Maksimov and Nikiforov 2007; Titova et al. 2010). The reactive species responsible for delignification are identified to be ozone, hydroxyl radicals, hydrogen peroxide generated during the discharge, and the bundles are later subjected to an alkaline wash to extract the degraded lignin components. Plasma treatments in deionized water have been investigated for degumming, where a reduction in pectin and lignin contents is observed likely due to hydronium ions generated during discharge (Henniges et al. 2012; Ying et al. 2016). Direct plasma treatments of unretted stalks is found to increase the hydrophobicity of materials (Baltazar-Y-Jimenez and Bismarck 2007), which is similar to the Duralin process discussed above.

\section{Summary and conclusion}

Investigations on the extraction of fibers from flax and hemp has been regaining ground over recent years, generally with a view to using them as fiber reinforcements in composites or in clothing (Baley et al. 2021; Manaia et al. 2019). The motivation for their use in composites is the equivalent performance but better sustainability profile compared to synthetics such as glass fibers (Bambach 2020). They also exhibit advantages over wood fibers in composites: longer fiber length (5-55 $\mathrm{mm}$ vs $1-5 \mathrm{~mm})$; lower lignin content (about $5 \% \mathrm{w} / \mathrm{w}$ vs about $30 \% \mathrm{w} / \mathrm{w}$ ); the lumen occupies a smaller area (0-5\% vs 20-70\%); and a lower MFA $\left(3-10^{\circ}\right.$ vs 3-50 $)$ (Madsen and Gamstedt 2013). The motivation for their use in clothing is the lower environmental impact of flax and hemp cultivation as compared to cotton (e.g. water consumption and pesticide use) (Baley et al. 2021; Möller and Popescu 2012).

Bast fiber bundles constitute only a portion of the plant dry mass (between 5-30\% in hemp and 35-40\% in flax) (Amaducci and Gusovius 2010; Hennink 1994; Horne 2012; Meijer 1995; Möller and Popescu 2012), and thus crops suitable only for fiber extraction may not be sufficient to sustain a viable agronomy. Hence, as mentioned above, efforts are underway to develop dual-use varieties. i.e. suitable for extraction of both seeds and for fibers.

Other investigations are directed towards developing varieties exhibiting improved tolerance to a wide range of environmental and soil factors so that cultivations may flourish in a wider set of locations thereby improving the global fiber output as well as improving local economies (Baldini et al. 2020; Goudenhooft et al. 2019; Żuk-Gołaszewska and Gołaszewski 2020). A better understanding of the molecular/genetic factors in the plant that affects fiber output and separation ease, along with improving the understanding of biotic and abiotic factors that affect microbial populations and their retting efficacies are other lines of investigation being followed (Djemiel et al. 2020; Mokshina et al. 2018; Shuvo 2020). Other efforts include investigations to establish agronomical best practices to match local soil quality and climate conditions, for example to identify optimal planting/ harvesting seasons, the optimal seeding densities, and on varieties best-suited for local conditions (Baldini et al. 2020; Baley et al. 2020; Goudenhooft et al. 2019).

The global output of flax and hemp fibers as compared to other materials they can potentially 
Table 2 Global output of flax and hemp fibers in 2019 (the latest year for which figures are available at the time of writing) compared to other materials for the same period

\begin{tabular}{lll}
\hline Material & Output (million metric tons) & Source \\
\hline Flax fiber and tow & 1.1 & FAOSTAT (2021) \\
Hemp tow waste & 0.2 & FAOSTAT (2021) \\
Mechanical and semi-chemical wood pulp (wood fiber) ${ }^{\mathrm{a}}$ & 35 & FAOSTAT (2021) \\
Glass fiber & 10 & Thomason (2019) \\
Cotton & 26 & Opperskalski et al. (2020) \\
Manmade cellulosic fibers & 7 & Opperskalski et al. (2020)
\end{tabular}

${ }^{a}$ Wood fibers for composites are derived primarily from mechanical and semi-chemical pulping processes, and hence their output figures are shown (Dai and Fan 2014)

replace in composites (wood fiber, glass fiber) and clothing (cotton, manmade cellulosics) are shown in Table 2. It is possible that not all of the conventional material output is employed in composites or clothing, but even then, it is clear to see that production volumes of flax and hemp fiber are dwarfed by outputs of the other materials. There are efforts to increase the output of flax and hemp as discussed above, but it should be remembered that both flax and hemp are recommended as rotation crops, to be planted only once in every few years. It is also to be noted that in any competition for arable land between food crops vs material/energy crops, the former needs to be favored over the latter. All these factors may limit the maximal global output volumes even with the best yields. Thus, care is required when considering the end-use applications of flax and hemp fibers, with focus perhaps on niche products or those aimed at a limited geographical range, as a wholescale replacement of conventional materials with flax and hemp appears difficult.

Authors' contribution Avinash P: Manian reviewed the literature and drafted the manuscript, Michael Cordin contributed with reviews of the literature, and Tung Pham contributed with reviews of the literature and of manuscript drafts.

Funding Open access funding provided by University of Innsbruck and Medical University of Innsbruck. The authors gratefully acknowledge funding from the Austrian Forschungsförderungsgesellschaft (FFG) for the project "BELCEL", and the Tiroler Innovationsförderung for the project "Alpenhanf 360".

\section{Declarations}

Conflict of interest None to declare.

Open Access This article is licensed under a Creative Commons Attribution 4.0 International License, which permits use, sharing, adaptation, distribution and reproduction in any medium or format, as long as you give appropriate credit to the original author(s) and the source, provide a link to the Creative Commons licence, and indicate if changes were made. The images or other third party material in this article are included in the article's Creative Commons licence, unless indicated otherwise in a credit line to the material. If material is not included in the article's Creative Commons licence and your intended use is not permitted by statutory regulation or exceeds the permitted use, you will need to obtain permission directly from the copyright holder. To view a copy of this licence, visit http://creativecommons.org/licenses/by/4.0/.

\section{References}

Adamsen APS, Akin DE, Rigsby LL (2002a) Chelating agents and enzyme retting of flax. Text Res J 72:296-302. https:// doi.org/10.1177/004051750207200404

Adamsen APS, Akin DE, Rigsby LL (2002b) Chemical retting of flax straw under alkaline conditions. Text Res J 72:789-794. 004051750207200907

https://doi.org/10.1177/

Adesina I, Bhowmik A, Sharma H, Shahbazi A (2020) A review on the current state of knowledge of growing conditions, agronomic soil health practices and utilities of hemp in the United States. Agriculture 10:129. https://doi.org/10.3390/ agriculture 10040129

Akin DE (2008) Plant cell wall aromatics: influence on degradation of biomass biofuels. Bioproducts and Biorefining 2:288-303. https://doi.org/10.1002/bbb.76

Akin DE (2010) Flax-structure, chemistry, retting and processing. In: Müssig J (ed) Industrial applications of natural fibres: structure, properties and technical applications. 
Wiley, pp 89-108. https://doi.org/10.1002/ 9780470660324.ch4

Akin DE (2013) Linen most useful: perspectives on structure, chemistry, and enzymes for retting flax ISRN biotechnology: Article ID 186534. https://doi.org/10.5402/2013/ 186534

Akin DE, Rigsby LL, Henriksson G, Eriksson KEL (1998) Structural effects on flax stems of three potential retting fungi. Text Res J 68:515-519. https://doi.org/10.1177/ 004051759806800708

Akin DE, Dodd RB, Perkins W, Henriksson G (2000) Eriksson K-EL spray enzymatic retting: a new method for processing flax fibers. Textile Res J 70:486-494. https://doi.org/ 10.1177/004051750007000604

Akin DE, Foulk JA, Dodd RB (2002) Influence on flax fibers of components in enzyme retting formulations. Text Res $\mathrm{J}$ 72:510-514. https://doi.org/10.1177/ 004051750207200608

Akin DE, Henriksson G, Evans JD, Adamsen APS, Foulk JA, Dodd RB (2004) Progress in enzyme-retting of flax. Journal of Natural Fibers 1:21-47. https://doi.org/10.1300/ J395v01n01_03

Akin DE, Condon B, Sohn M, Foulk JA, Dodd RB, Rigsby LL (2007) Optimization for enzyme-retting of flax with pectate lyase. Ind Crops Prod 25:136-146. https://doi.org/10. 1016/j.indcrop.2006.08.003

Alix S, Lebrun L, Marais S, Philippe E, Bourmaud A, Baley C, Morvan C (2012) Pectinase treatments on technical fibres of flax: effects on water sorption and mechanical properties. Carbohyd Polym 87:177-185. https://doi.org/10. 1016/j.carbpol.2011.07.035

Amaducci S (2005) Hemp production in Italy. J Ind Hemp 10:109-115. https://doi.org/10.1300/J237v10n01_09

Amaducci S, Gusovius HJ (2010) Hemp-cultivation, extraction and processing. In: Müssig J (ed) Industrial applications of natural fibres: structure, properties and technical applications. Wiley, pp 109-134. https://doi.org/10.1002/ 9780470660324.ch5

Amaducci S, Colauzzi M, Bellocchi G, Venturi G (2008) Modelling post-emergent hemp phenology Cannabis sativa L Theory and evaluation. Eur J Agronomy 28:90-102. https://doi.org/10.1016/j.eja.2007.05.006

Assirelli A, Dal Re L, Esposito S, Cocchi A, Santangelo E (2020) The mechanical harvesting of hemp using in-field stand-retting: a simpler approach converted to the production of fibers for industrial use. Sustainability 12:8795. https://doi.org/10.3390/su12218795

Baldini M, Ferfuia C, Zuliani F, Danuso F (2020) Suitability assessment of different hemp (Cannabis sativa $L$.) varieties to the cultivation environment. Ind Crops Prod 143:111860. https://doi.org/10.1016/j.indcrop.2019. 111860

Baley C et al (2019) Specific features of flax fibres used to manufacture composite materials. IntJ Mater Form 12:1023-1052. https://doi.org/10.1007/s12289-018-1455$\mathrm{y}$

Baley C, Gomina M, Breard J, Bourmaud A, Davies P (2020) Variability of mechanical properties of flax fibres for composite reinforcement. A review. Ind Crops Prod 145:111984. https://doi.org/10.1016/j.indcrop.2019. 111984
Baley C, Bourmaud A, Davies P (2021) Eighty years of composites reinforced by flax fibres: a historical review. Compos A Appl Sci Manuf 144:106333. https://doi.org/10. 1016/j.compositesa.2021.106333

Baltazar-Y-Jimenez A, Bismarck A (2007) Surface modification of lignocellulosic fibres in atmospheric air pressure plasma. Green Chem 9:1057-1066. https://doi.org/10. 1039/B618398K

Bambach MR (2020) Direct Comparison of the Structural Compression Characteristics of Natural and Synthetic Fiber-Epoxy Composites: Flax, Jute, Hemp. Glass and Carbon Fibers Fibers 8:62

Beltran R, Hurren CJ, Kaynak A, Wang X (2002) Correlating the fineness and residual gum content of degummed hemp fibres. Fibers and Polymers 3:129-133. https://doi.org/10. 1007/BF02912656

Bewley-Taylor D, Blickman T, Jelsma M (2014) The rise and decline of cannabis prohibition. Transnational Institute (TNI), Amsterdam/Swansea. https://www.tni.org/en/ publication/the-rise-and-decline-of-cannabis-prohibition

Bleuze L, Chabbert B, Lashermes G, Recous S (2020) Hemp harvest time impacts on the dynamics of microbial colonization and hemp stems degradation during dew retting. Ind Crops Prod 145:112122. https://doi.org/10.1016/j. indcrop.2020.112122

Bonnin E, Ralet MC, Thibault JF, Schols HA (2009) Enzymes for the valorisation of fruit- and vegetable-based co-products. In: Waldron K (ed) Handbook of waste management and co-product recovery in food processing. Woodhead Publishing, pp 257-285. https://doi.org/10.1533/ 9781845697051.3.257

Camarero S et al (2004) Efficient bleaching of non-wood highquality paper pulp using laccase-mediator system. Enzyme Microb Technol 35:113-120. https://doi.org/10.1016/j. enzmictec.2003.10.019

Campbell BJ, Berrada AF, Hudalla C, Amaducci S, McKay JK (2019) Genotype $\times$ environment interactions of industrial hemp cultivars highlight diverse responses to environmental factors Agrosystems. Geosci Environ 2:180057. https://doi.org/10.2134/age2018.11.0057

Carlson SL (2008) An integrated approach to investigating the reintroduction of flax production in Iowa. Masters thesis, Iowa State University. https://lib.dr.iastate.edu/rtd/15337/

Chabbert B, Kurek B, Beherec O (2013) Physiology and botany of industrial hemp. In: Bouloc P, Allegret S, Arnaud L (eds) Hemp: industrial production and uses. CAB International, Oxfordshire, pp 27-47

Chabbert B et al (2020) Multimodal assessment of flax dew retting and its functional impact on fibers and natural fiber composites. Ind Crops Prod 148:112255. https://doi.org/ 10.1016/j.indcrop.2020.112255

Chernova T, Mikshina P, Salnikov V, Ageeva M, Ibragimova N, Sautkina O, Gorshkova T (2017) Development of hemp fibers: the key components of hemp plastic composites, natural and artificial fiber-reinforced composites as renewable sources. In: Günay E (ed) Natural and artificial fiber-reinforced composites as renewable sources. IntechOpen, pp 41-56. https://doi.org/10.5772/intechopen. 70976

Chernova TE, Mikshina PV, Salnikov VV, Ibragimova NN, Sautkina OV, Gorshkova TA (2018) Development of 
distinct cell wall layers both in primary and secondary phloem fibers of hemp Cannabis sativa L. Industrial Crops and Products 117:97-109. https://doi.org/10.1016/j. indcrop.2018.02.082

Cheshkova AV, Zavadskii AE, Loginova VA (2013) New biochemical approaches to fiber modification in the solution of the problem of unifying cellulose pretreatment technologies. Russ J Gen Chem 83:177-184. https://doi.org/10. 1134/S1070363213010386

Christopher LP, Yao B, Ji Y (2014) Lignin biodegradation with Laccase-mediator systems. Front Energy Res. https://doi. org/10.3389/fenrg.2014.00012

Clair B, Déjardin A, Pilate G, Alméras T (2018) Is the G-layer a tertiary cell wall? Front Plant Sci. https://doi.org/10.3389/ fpls.2018.00623

Clarke RC (1999) Botany of the Genus Cannabis In: Ranalli P (ed) Advances in hemp research. CRC Press, Boca Raton, pp 1-19. https://doi.org/10.1201/9781498705820

Correia F, Roy DN, Goel K (2001) Chemistry and delignification kinetics of Canadian industrial hemp Cannabis sativa L. J Wood Chem Technol 21:97-111. https://doi.org/10. 1081/WCT-100104221

Crini G, Lichtfouse E, Chanet G, Morin-Crini N (2020) Applications of hemp in textiles, paper industry, insulation and building materials, horticulture, animal nutrition, food and beverages, nutraceuticals, cosmetics and hygiene, medicine, agrochemistry, energy production and environment: a review. Environ Chem Lett 18:1451-1476. https://doi.org/ 10.1007/s10311-020-01029-2

Dai D, Fan M (2014) Wood fibres as reinforcements in natural fibre composites: structure, properties, processing and applications. In: Hodzic A, Shanks R (eds) Natural fibre composites. Woodhead Publishing, pp 3-65. https://doi. org/10.1533/9780857099228.1.3

Danielewicz D, Surma-Slusarska B (2011) Oxygen delignification and bleaching of industrial hemp pulps. Fibres \& Textiles in Eastern Europe 19:84-88

De Prez J, Van Vuure AW, Ivens J, Aerts G, Van de Voorde I (2019a) Effect of enzymatic treatment of flax on chemical composition and the extent of fiber separation. BioResources 14:3012-3030. https://doi.org/10.15376/biores.14. 2.3012-3030

De Prez J, Van Vuure AW, Ivens J, Aerts G, Van de Voorde I (2019b) Effect of enzymatic treatment of flax on fineness of fibers and mechanical performance of composites. Compos A Appl Sci Manuf 123:190-199. https://doi.org/10.1016/j. compositesa.2019.05.007

De PJ, Aerts G, Van dVI, Van VAW, Ivens J (2018) Enzymatic treatment of flax for use in composites Biotechnology Reports 20:e00294. https://doi.org/10.1016/j.btre.2018. e00294

de Vega A, Ligero P (2017) Formosolv fractionation of hemp hurds. Ind Crops Prod 97:252-259. https://doi.org/10. 1016/j.indcrop.2016.12.021

de Groot B, van Dam JEG, van tRietK (1995) Alkaline pulping of hemp woody core: kinetic modeling of lignin, xylan and cellulose extraction and degradation. Holzforschung 49:332-342. https://doi.org/10.1515/hfsg.1995.49.4.332

Denisova MN, Budaeva VV, Pavlov IN (2015) Pulps isolated from Miscanthus, oat hulls, and intermediate flax straw with sodium benzoate. Korean J Chem Eng 32:202-205. https://doi.org/10.1007/s11814-014-0371-1

Desanlis F, Cerruti N, Warner P (2013) Hemp Agronomics and cultivation. In: Bouloc P, Allegret S, Arnaud L (eds) Hemp: industrial production and uses. CAB International, Oxfordshire, pp 98-124

Dhondt FBEP (2020) The future of hemp fibres under changing climate conditions. Bachelors Thesis, Amsterdam University of Applied Sciences. https://doi.org/10.13140/ RG.2.2.28871.52643

Di Candilo M, Ranalli P, Bozzi C, Focher B, Mastromei G (2000) Preliminary results of tests facing with the controlled retting of hemp. Ind Crops Prod 11:197-203. https://doi.org/10.1016/S0926-6690(99)00047-3

Di Candilo M, Bonatti PM, Guidetti C, Focher B, Grippo C, Tamburini E, Mastromei G (2010) Effects of selected pectinolytic bacterial strains on water-retting of hemp and fibre properties. J Appl Microbiol 108:194-203. https://doi. org/10.1111/j.1365-2672.2009.04409.x

Dijon GG, Baillie C, Murphy R A study of the structure and the tensile properties of flax fibers. In: 6th International Conference on Woodfiber-Plastic Composites, Wisconsin, USA, May 15-16 2002. Forest Products Society, pp 21-25

Djemiel C, Goulas E, Badalato N, Chabbert B, Hawkins S, Grec S (2020) Targeted Metagenomics of Retting in Flax: The Beginning of the Quest to Harness the Secret Powers of the Microbiota. Front Genetics. https://doi.org/10.3389/fgene. 2020.581664

Donaghy JA, Boomer JH, Haylock RW (1992) An assessment of the quality and yield of flax fiber produced by the use of pure bacterial cultures in flax rets. Enzyme Microb Technol 14:131-134. 0229(92)90170-S

https://doi.org/10.1016/0141-

Dorado J, Almendros G, Field JA, Sierra-Alvarez R (2001) Infrared spectroscopy analysis of hemp (Cannabis sativa) after selective delignification by Bjerkandera sp. at different nitrogen levels. Enzyme Microbial Technol 28:550-559. https://doi.org/10.1016/S01410229(00)00363-X

Dorado J, Field JA, Almendros G, Sierra-Alvarez R (2001) Nitrogen-removal with protease as a method to improve the selective delignification of hemp stemwood by the whiterot fungus Bjerkandera sp. strain BOS55. Appl Microbiol Biotechnol 57:205-211. https://doi.org/10.1007/ s002530100737

Easson DL, Cooper K (2002) A study of the use of the trimesium salt of glyphosate to desiccate and ret flax and linseed (Linum usitatissimum) and of its effects on the yield of straw, seed and fibre. J Agricultural Sci 138:29-37. https:// doi.org/10.1017/S0021859601001629

Easson DL, Molloy R, Anderson R, Sharma HSS (1998) The retting of flax after preservation with sulfur dioxide. Ann Appl Biol 133:467-481. https://doi.org/10.1111/j.17447348.1998.tb05844.x

European Commission EU Plant variety database (v.3.2.1) Species A - 85 - Hemp - Cannabis sativa. https://ec.europa. eu/food/plant/plant_propagation_material/plant_variety_ catalogues_databases/search/public/index.cfm?event= SearchVariety\&ctl_type $=$ A\&species_id $=240 \&$ variety name $=\&$ listed_in $=0 \&$ show_current $=$ on $\&$ show_deleted $=$. Accessed 09 Feb 2021 
European Commission EU Plant variety database (v.3.2.1) Species A - 90 - Flax, Linseed - Linum usitatissimum. https://ec.europa.eu/food/plant/plant_propagation_ material/plant_variety_catalogues_databases/search/ public/index.cfm?event=SearchVariety\&ctl_type $=$ A\&species_id=245\&variety_name $=\&$ listed_in $=0 \&$ show current $=$ on\&show_deleted $=$. Accessed 09 Feb 2021

Evans JD, Akin DE, Foulk JĀ (2002) Flax-retting by polygalacturonase-containing enzyme mixtures and effects on fiber properties. J Biotechnol 97:223-231. https://doi.org/ 10.1016/S0168-1656(02)00066-4

FAOSTAT (2021) Food and agriculture data. http://www.fao. org/faostat/en/\#home.

Fernando D, Thygesen A, Meyer AS, Daniel G (2019) Elucidating field retting mechanisms of hemp fibres for biocomposites: effects of microbial actions and interactions on the cellular micro-morphology and ultrastructure of hemp stems and bast fibres. BioResources 14:4047-4084

Fike J (2016) Industrial hemp: renewed opportunities for an ancient crop. Crit Rev Plant Sci 35:406-424. https://doi. org/10.1080/07352689.2016.1257842

Fillat U, Blanca Roncero M (2009) Effect of process parameters in laccase-mediator system delignification of flax pulp. Chem Eng J 152:322-329. https://doi.org/10.1016/j.cej. 2009.05.036

Fillat U, Roncero MB (2009a) Biobleaching of high quality pulps with laccase mediator system: Influence of treatment time and oxygen supply. Biochem Eng J 44:193-198. https://doi.org/10.1016/j.bej.2008.12.002

Fillat U, Roncero MB (2009b) Optimization of laccase-mediator system in producing biobleached flax pulp. Biores Technol 101:181-187. https://doi.org/10.1016/j.biortech.2009.07. 020

Fillat A, Colom JF, Vidal T (2010) A new approach to the biobleaching of flax pulp with laccase using natural mediators. Biores Technol 101:4104-4110. https://doi.org/ 10.1016/j.biortech.2010.01.057

Fillat A, Roncero MB, Vidal T (2011) Assessing the use of xylanase and laccases in biobleaching stages of a TCF sequence for flax pulp. J Chem Technol Biotechnol 86:1501-1507. https://doi.org/10.1002/jctb.2662

Fillat A, Roncero MB, Vidal T (2012) Elucidating the effects of laccase-modifying compounds treatments on bast and core fibers in flax pulp. Biotechnol Bioeng 109:225-233. https:// doi.org/10.1002/bit.23278

Fischer H, Muessig J, Bluhm C (2006) Enzymatic modification of hemp fibres for sustainable production of high quality materials: influence of processing parameters. J Natural Fibers 3:39-53. https://doi.org/10.1300/J395v03n02_03

Fu Y-B (2011) Genetic evidence for early flax domestication with capsular dehiscence. Genet Resour Crop Evol 58:1119-1128. https://doi.org/10.1007/s10722-010-96509

Fu D, Mazza G, Tamaki Y (2010) Lignin extraction from straw by ionic liquids and enzymatic hydrolysis of the cellulosic residues. J Agric Food Chem 58:2915-2922. https://doi. org/10.1021/jf903616y

Garcia-Jaldon C, Dupeyre D, Vignon MR (1998) Fibers from semi-retted hemp bundles by steam explosion treatment. Biomass Bioenergy 14:251-260. https://doi.org/10.1016/ S0961-9534(97)10039-3
Gorchs G, Lloveras J, Serrano L, Cela S (2017) Hemp yields and its rotation effects on wheat under rainfed mediterranean conditions. Agron J 109:1551-1560. https://doi.org/10. 2134/agronj2016.11.0676

Gorshkova T et al (2012) Plant fiber formation: State of the art, recent and expected progress, and open questions. Crit Rev Plant Sci 31:201-228. https://doi.org/10.1080/07352689. 2011.616096

Gorshkova T, Mikshina P, Petrova A, Chernova T, Mokshina N, Gorshkov O (2018) Plants at bodybuilding: development of plant "Muscles". In: Geitmann A, Gril J (eds) Plant biomechanics: from structure to function at multiple scales. Springer International Publishing, Cham, pp 141-163. https://doi.org/10.1007/978-3-319-79099-2_7

Gosselink RJA, van Dam JEG, Zomers FHA (1995) Combined HPLC analysis of organic acids and furans formed during organosolv pulping of fiber hemp. J Wood Chem Technol 15:1-25. https://doi.org/10.1080/02773819508009497

Goudenhooft C, Bourmaud A, Baley C (2019) Flax (Linum usitatissimum L.) Fibers for composite reinforcement: exploring the link between plant growth, cell walls development, and fiber properties. Frontiers in Plant Science 10, Article 411. https://doi.org/10.3389/fpls.2019.00411

Gregoire M, De Luycker E, Bar M, Musio S, Amaducci S, Ouagne P (2019) Study of solutions to optimize the extraction of hemp fibers for composite materials SN. Appl Sci 1:1-6. https://doi.org/10.1007/s42452-019-1332-4

Gusovius H-J, Hoffmann T, Budde J, Lühr C (2016) Still special? Harvesting procedures for industrial hemp LANDTECHNIK /. Agricultural Eng 71:14-24. https://doi.org/ 10.15150/lt.2016.3118

Gusovius H-J, Luehr C, Hoffmann T, Pecenka R, Idler C (2019) An alternative to field retting: fibrous materials based on wet preserved hemp for the manufacture of composites. Agriculture (Basel, Switz) 9:140. https://doi.org/10.3390/ agriculture 9070140

Haenninen T, Thygesen A, Mehmood S, Madsen B, Hughes M (2012) Mechanical processing of bast fibres: the occurrence of damage and its effect on fibre structure Ind Crops. Prod 39:7-11. https://doi.org/10.1016/j.indcrop.2012.01. 025

Harvey BMR, Crothers SH (1988) Pre-harvest retting of flax: effects of water stress on uptake and efficacy of glyphosate. Ann Appl Biol 113:61-68. https://doi.org/10.1111/j.17447348.1988.tb03282.x

Harvey BMR, Crothers SH, Courtney AD (1985) Pre-harvest retting of flax: uptake, translocation and efficacy of glyphosate applied to flax in a dry year. Record of Agricultural Res 33:87-93

Harwood J, McCormick P, Waldron D, Bonadei R (2008) Evaluation of flax accessions for high value textile end uses. Ind Crops Prod 27:22-28. https://doi.org/10.1016/j. indcrop.2007.06.004

Heller K et al (2015) A comparative study between Europe and China in crop management of two types of flax: linseed and fibre flax. Ind Crops Prod 68:24-31. https://doi.org/10. 1016/j.indcrop.2014.07.010

Henglein FA (1969) The processing of products of the chemical industry and the application of its process technology to the production of consumer goods. In: Henglein FA (ed) 
Chemical technology. Pergamon, pp 696-841. https://doi. org/10.1016/B978-0-08-011848-2.50015-5

Henniges U, Okubayashi S, Rosenau T, Potthast A (2012) Irradiation of cellulosic pulps: understanding its impact on cellulose oxidation. Biomacromol 13:4171-4178. https:// doi.org/10.1021/bm3014457

Hennink S (1994) Optimisation of breeding for agronomic traits in fibre hemp (Cannabis sativa L) by study of parent-offspring relationships. Euphytica 78:69-76. https://doi.org/ 10.1007/BF00021399

Henriksson G, Eriksson K-EL, Kimmel L, Akin DE (1998) Chemical/physical retting of flax using detergent and oxalic acid at high pH. Text Res J 68:942-947. https://doi. org/10.1177/004051759806801210

Henriksson G, Akin DE, Hanlin RT, Rodriguez C, Archibald DD, Rigsby LL, Eriksson K-EL (1997) Identification and retting efficiencies of fungi isolated from dew-retted flax in the United States and Europe. Appl Environ Microbiol 63:3950-3956. https://doi.org/10.1128/aem.63.10.39503956.1997

Hepworth DG, Hobson RN, Bruce DM, Farrent JW (2000) The use of unretted hemp fibre in composite manufacture. Composites Part A 31A:1279-1283. https://doi.org/10. 1016/S1359-835X(00)00098-1

Horne MRL (2012) Bast fibres: hemp cultivation and production. In: Kozłowski RM (ed) Handbook of natural fibres, vol 1. Woodhead Publishing, pp 114-145. https://doi.org/ 10.1533/9780857095503.1.114

Huang S, Huang D, Wu Q, Hou M, Tang X, Zhou J (2020) Effect of environmental $\mathrm{C} / \mathrm{N}$ ratio on activities of lignin-degrading enzymes produced by Phanerochaete chrysosporium. Pedosphere 30:285-292. https://doi.org/10.1016/S10020160(17)60391-6

Jankauskiene Z, Butkute B, Gruzdeviene E, Ceseviciene J, Fernando AL (2015) Chemical composition and physical properties of dew- and water-retted hemp fibers. Ind Crops Prod 75:206-211. https://doi.org/10.1016/j.indcrop.2015. 06.044

John F (2019) The history of hemp. In: Williams DW (ed) Industrial hemp as a modern commodity crop. American Society of Agronomy, Crop Science Society of America, and Soil Science Society of America, pp 1-25. https://doi. org/10.2134/industrialhemp.c1

Juarez AGV, Rost G, Heitmann U, Heger E, Mueller R (2013) Construction of a pilot plant for producing fine linen fibers for textiles. Biochem Eng J 71:11-18. https://doi.org/10. 1016/j.bej.2012.11.010

Keller A, Leupin M, Mediavilla V, Wintermantel E (2001) Influence of the growth stage of industrial hemp on chemical and physical properties of the fibres. Ind Crops Prod 13:35-48. https://doi.org/10.1016/S09266690(00)00051-0

Kessler RW, Becker U, Kohler R, Goth B (1998) Steam explosion of flax - a superior technique for upgrading fiber value. Biomass Bioenergy 14:237-249. https://doi.org/10. 1016/S0961-9534(97)10040-X

Kim J-W, Mazza G (2009) Extraction and separation of carbohydrates and phenolic compounds in flax shives with pH-controlled pressurized low polarity water. J Agric Food Chem 57:1805-1813. https://doi.org/10.1021/jf803467y
Kiyoto S, Yoshinaga A, Fernandez-Tendero E, Day A, Chabbert B, Takabe K (2018) Distribution of lignin, hemicellulose, and arabinogalactan protein in hemp phloem fibers. Microsc Microanal 24:442-452. https://doi.org/10.1017/ S1431927618012448

Kopania E, Wietecha J, Ciechanska D (2012) Studies on isolation of cellulose fibres from waste plant biomass. Fibres \& Textiles in Eastern Europe 20:167-172

Kozasowski RM, Mackiewicz-Talarczyk M, Allam AM (2012) Bast fibres: flax. In: Kozłowski RM (ed) Handbook of natural fibres, vol 1. Woodhead Publishing, pp 56-113. https://doi.org/10.1533/9780857095503.1.56

Kvavadze E, Bar-Yosef O, Belfer-Cohen A, Boaretto E, Jakeli N, Matskevich Z, Meshveliani T (2009) 30,000-Year-old wild flax fibers. Science 325:1359-1359. https://doi.org/ 10.1126/science. 1175404

Kymalainen HR, Koivula M, Kuisma R, Sjoberg AM, Pehkonen A (2004) Technologically indicative properties of straw fractions of flax, linseed (Linum usitatissimum L.) and fibre hemp (Cannabis sativa L). Bioresour Technol 94:57-63. https://doi.org/10.1016/j.biortech.2003.11.027

Li Y, Pickering KL, Farrell RL (2009) Analysis of green hemp fibre reinforced composites using bag retting and white rot fungal treatments. Ind Crops Prod 29:420-426. https://doi. org/10.1016/j.indcrop.2008.08.005

Liu M, Silva DAS, Fernando D, Meyer AS, Madsen B, Daniel G, Thygesen A (2016) Controlled retting of hemp fibres: Effect of hydrothermal pre-treatment and enzymatic retting on the mechanical properties of unidirectional hemp/epoxy composites. Compos A Appl Sci Manuf 88:253-262. https://doi.org/10.1016/j.compositesa.2016.06.003

Liu M, Thygesen A, Summerscales J, Meyer AS (2017) Targeted pre-treatment of hemp bast fibers for optimal performance in biocomposite materials: a review. Ind Crops Prod 108:660-683. https://doi.org/10.1016/j.indcrop.2017. 07.027

Liu Q, Luo L, Zheng L (2018) Lignins: Biosynthesis and Biological Functions in Plants. Int J Molecular Sci 19:335. https://doi.org/10.3390/ijms19020335

Madsen B, Gamstedt EK (2013) Wood versus Plant Fibers: Similarities and Differences in Composite Applications. Adv Mater Sci Eng 2013:564346. https://doi.org/10.1155/ 2013/564346

Magnusson K, Svennerstedt B (2007) Influence of temperature on the water retting process of hemp (Cannabis sativa L.) cultivated under swedish climate conditions. J Ind Hemp 12:3-17. https://doi.org/10.1300/J237v12n02_02

Maksimov AI, Nikiforov AY (2007) Comparison of plasma and plasma-solution modifications of polymer materials in the liquid phase. High Energy Chem 41:454-459. https://doi. org/10.1134/S0018143907060124

Manaia JP, Manaia AT, Rodriges L (2019) Industrial Hemp Fibers: an Overview Fibers 7:106

Martin N, Mouret N, Davies P, Baley C (2013) Influence of the degree of retting of flax fibers on the tensile properties of single fibers and short fiber/polypropylene composites. Ind Crops Prod 49:755-767. https://doi.org/10.1016/j.indcrop. 2013.06.012

Mazian B, Cariou S, Chaignaud M, Fanlo J-L, Fauconnier M-L, Bergeret A, Malhautier L (2019) Evolution of temporal dynamic of volatile organic compounds (VOCs) and odors 
of hemp stem during field retting. Planta 250:1983-1996. https://doi.org/10.1007/s00425-019-03280-6

Meijer EPM (1995) Fibre hemp cultivars: A survey of origin, ancestry, availability and brief agronomic characteristics. J Int Hemp Association 2:66-73

Meijer WJM, Vertregt N, Rutgers B, van de Waart M (1995) The pectin content as a measure of the retting and rettability of flax. Ind Crops Prod 4:273-284. https://doi.org/10. 1016/0926-6690(95)00041-0

Mokshina N, Chernova T, Galinousky D, Gorshkov O, Gorshkova T (2018) Key stages of fiber development as determinants of bast fiber yield and quality. Fibers 6:20

Möller M, Popescu C (2012) Natural Fibers. In: Matyjaszewski K, Möller M (eds) Polymer Science: A Comprehensive Reference. Elsevier, Amsterdam, pp 267-280. https://doi. org/10.1016/B978-0-444-53349-4.00266-1

Mooney C, Stolle-Smits T, Schols H, de Jong E (2001) Analysis of retted and non retted flax fibres by chemical and enzymatic means. J Biotechnol 89:205-216. https://doi.org/10. 1016/S0168-1656(01)00299-1

Morrison WH III (2000) Defining flax quality. Agro Food Industry Hi-Tech 11:14-16

Morrison WH III, Archibald DD, Sharma HSS, Akin DE (2000) Chemical and physical characterization of water- and dewretted flax fibers. Ind Crops Prod 12:39-46. https://doi.org/ 10.1016/S0926-6690(99)00044-8

Mustata A (1994) Superficial delignification of flax fibers separated from undecayed stems. Cellul Chem Technol 28:65-69

Muzyczek M (2012) The use of flax and hemp for textile applications. In: Kozłowski RM (ed) Handbook of natural fibres, vol 2. Woodhead Publishing, pp 312-328. https:// doi.org/10.1533/9780857095510.2.312

Nair GR, Kurian J, Yaylayan V, Rho D, Lyew D, Raghavan GSV (2014) Microwave-assisted retting and optimization of the process through chemical composition analysis of the matrix. Ind Crops Prod 52:85-94. https://doi.org/10. 1016/j.indcrop.2013.10.007

Nair GR, Lyew D, Yaylayan V, Raghavan V (2015) Application of microwave energy in degumming of hemp stems for the processing of fibres. Biosys Eng 131:23-31. https://doi. org/10.1016/j.biosystemseng.2014.12.012

Opperskalski S, Siew S, Tan E, Truscott L (2020) Preferred fiber \& materials market report 2020. Textile Exchange. https:// textileexchange.org/2020-preferred-fiber-and-materialsmarket-report-pfmr-released/

Pacaphol K, Aht-Ong D (2017) Preparation of hemp nanofibers from agricultural waste by mechanical defibrillation in water. J Clean Prod 142:1283-1295. https://doi.org/10. 1016/j.jclepro.2016.09.008

Pandey BP (2005) A Textbook of Botany: angiosperms. S. Chand \& Company Ltd., New Delhi

Pandey R, Jose S, Basu G, Sinha MK (2019) Novel methods of degumming and bleaching of indian flax variety tiara. J Nat Fibers. Ahead of Print. https://doi.org/10.1080/15440478. 2019.1687067

Pasila A (2000) The effect of frost on fibre plants and their processing molecular crystals and liquid crystals science and technology section A. Mol Cryst Liq Cryst 353:11-22. https://doi.org/10.1080/10587250008025644
Pejić BM, Kramar AD, Obradović BM, Kuraica MM, Žekić AA, Kostić MM (2020) Effect of plasma treatment on chemical composition, structure and sorption properties of lignocellulosic hemp fibers (Cannabis sativa L). Carbohydrate Polym 236:116000. https://doi.org/10.1016/j.carbpol. 2020.116000

Petrova SN, Volkova IY, Zakharov AG (2003) Oxidative delignification of flax fiber. Russ J Appl Chem 76:1344-1347. https://doi.org/10.1023/B:RJAC. 0000008315.55283 .89

Petrova SN, Volkova IY, Zakharov AG (2004) Kinetics of alkaline delignification of flax fibre. Fibre Chem 36:393-395. https://doi.org/10.1007/s10692-005-0024-6

Piotrowski S, Carus M (2011) Ecological benefits of hemp and flax cultivation and products. nova-Institut $\mathrm{GmbH}$. https:// eiha.org/studies/ecological-benefits-of-hemp-and-flaxcultivation-and-products/

Placet V, Day A, Beaugrand J (2017) The influence of unintended field retting on the physicochemical and mechanical properties of industrial hemp bast fibres. J Mater Sci 52:5759-5777. https://doi.org/10.1007/s10853-017-08115

Pott GT (2002) Reduction of moisture sensitivity in natural fibres mater. Res Soc Symp Proc 702:87-98

Rahman MMM, Sayed-Esfahani MH (1979) Study of surface characteristics of hemp fibres using scanning electron microscopy. Indian J Textile Res 4:115-120

Ramesh M (2018) Hemp, jute, banana, kenaf, ramie, sisal fibers. In: Bunsell AR (ed) Handbook of properties of textile and technical fibres (Second Edition). Woodhead Publishing, pp 301-325. https://doi.org/10.1016/B978-0-08-101272-7. 00009-2

Ramesh M (2019) Flax (Linum usitatissimum L.) fibre reinforced polymer composite materials: a review on preparation, properties and prospects. Progress in Mater Sci 102:109-166. https://doi.org/10.1016/j.pmatsci.2018.12. 004

Ranalli P (1999) Agronomical and physiological advances in hemp crops. In: Ranalli P (ed) Advances in hemp research. CRC Press, Boca Raton, pp 61-84. https://doi.org/10.1201/ 9781498705820

Réquilé S, Goudenhooft C, Bourmaud A, Le Duigou A, Baley C (2018a) Exploring the link between flexural behaviour of hemp and flax stems and fibre stiffness. Ind Crops Prod 113:179-186. https://doi.org/10.1016/j.indcrop.2018.01. 035

Réquilé S, Le Duigou A, Bourmaud A, Baley C (2018b) Peeling experiments for hemp retting characterization targeting biocomposites. Ind Crops Prod 123:573-580. https://doi. org/10.1016/j.indcrop.2018.07.012

Réquilé $\mathrm{S}$ et al (2021) Exploring the dew retting feasibility of hemp in very contrasting European environments: Influence on the tensile mechanical properties of fibres and composites. Ind Crops Prod 164:113337. https://doi.org/ 10.1016/j.indcrop.2021.113337

Ribeiro A et al (2015) Microbial diversity observed during hemp retting. Appl Microbiol Biotechnol 99:4471-4484. https:// doi.org/10.1007/s00253-014-6356-5

Rognes H, Gellerstedt G, Henriksson G (2000) Optimization of flax fiber separation by leaching. Cellul Chem Technol $34: 331-340$ 
Ruan P, Du J, Raghavan V, Lyew D, Gariepy Y, Yang H (2020a) Microwave pretreated enzymatic retting of flax stems and comparison with the effect of radio frequency pretreatment. Ind Crops Prod 151:112312. https://doi.org/10.1016/ j.indcrop.2020.112312

Ruan P, Raghavan V, Du J, Gariepy Y, Lyew D, Yang H (2020b) Effect of radio frequency pretreatment on enzymatic retting of flax stems and resulting fibers properties. Ind Crops Prod 146:112204. https://doi.org/10.1016/j.indcrop.2020. 112204

Sadrmanesh V, Chen Y (2019) Bast fibres: structure, processing, properties, and applications. Int Mater Rev 64:381-406. https://doi.org/10.1080/09506608.2018.1501171

Salmon-Minotte J, Franck RR (2005) Flax. In: Franck RE (ed) Bast and other plant fibres. Woodhead Publishing, pp 94-175. https://doi.org/10.1533/9781845690618.94

Sampaio S, Bishop D, Shen J (2005) Physical and chemical properties of flax fibers from stand-retted crops desiccated at different stages of maturity. Ind Crops Prod 21:275-284. https://doi.org/10.1016/j.indcrop.2004.04.001

Sharma HSS (1986) Effects of the application of chemical additives to desiccated flax on retting. Biotech Lett 8:219-223. https://doi.org/10.1007/BF01029384

Sharma HSS (1988) Chemical retting of flax using chelating compounds. Ann Appl Biol 113:159-165. https://doi.org/ 10.1111/j.1744-7348.1988.tb03292.x

Sharma HSS, McCall RD, Faughey G, Lyons G (1999) Effects of sulfur dioxide preservation of flax straw on fiber components and microbial colonization during dew-retting. Ann Appl Biol 134:215-223. https://doi.org/10.1111/j. 1744-7348.1999.tb05257.x

Shekhar Sharma HS, Mercer PC, Brown AE (1989) A review of recent research on the retting of flax in Northern Ireland. Int Biodeterior 25:327-342. https://doi.org/10.1016/02653036(89)90013-4

Shishonok MV, Shadrina VI (2006) Recovery of wool from flax fibers using nitric acid. Russ J Appl Chem 79:1542-1545. https://doi.org/10.1134/S1070427206090291

Shuvo II (2020) Fibre attributes and mapping the cultivar influence of different industrial cellulosic crops (cotton, hemp, flax, and canola) on textile properties. Biores Bioprocess 7:51. https://doi.org/10.1186/s40643-020-00339-1

Sisti L, Totaro G, Vannini M, Fabbri P, Kalia S, Zatta A, Celli A (2016) Evaluation of the retting process as a pre-treatment of vegetable fibers for the preparation of high-performance polymer biocomposites Ind Crops. Prod 81:56-65. https:// doi.org/10.1016/j.indcrop.2015.11.045

Snegireva A, Chernova T, Ageeva M, Lev-Yadun S, Gorshkova $T$ (2015) Intrusive growth of primary and secondary phloem fibres in hemp stem determines fibre-bundle formation and structure. AoB PLANTS 7. https://doi.org/10. 1093/aobpla/plv061

Sponner J, Toth L, Cziger S, Franck RR (2005) Hemp. In: Franck RE (ed) Bast and other plant fibres. Woodhead Publishing, pp 176-206. https://doi.org/10.1533/ 9781845690618.176

Stamboulis A, Baillie CA, Peijs T (2001) Effects of environmental conditions on mechanical and physical properties of flax fibers. Compos A Appl Sci Manuf 32:1105-1115. https://doi.org/10.1016/S1359-835X(01)00032-X
Stewart D, Morrison IM (1996) Delignification and bleaching of non-wood fibers with peroxy-compounds. In: Kennedy JF, Phillips G, Williams P (eds) Cellucon '94, Bangor, UK, Woodhead, pp 133-141

Tamburini E, León AG, Perito B, Mastromei G (2003) Characterization of bacterial pectinolytic strains involved in the water retting process. Environ Microbiol 5:730-736. https://doi.org/10.1046/j.1462-2920.2003.00462.x

Tamburini E, León AG, Perito B, Di Candilo M, Mastromei G (2004) Exploitation of bacterial pectinolytic strains for improvement of hemp water retting. Euphytica 140:47-54. https://doi.org/10.1007/s10681-004-4754-y

Thomason JL (2019) Glass fibre sizing: A review. Compos A Appl Sci Manuf 127:105619. https://doi.org/10.1016/j. compositesa.2019.105619

Titova YV, Stokozenko VG, Maximov AI (2010) Application of underwater discharge for modification of cellulose materials. IEEE Trans Plasma Sci 38:933-936. https://doi.org/ 10.1109/TPS.2010.2042181

Tourangeau W (2015) Re-defining environmental harms: green criminology and the State of Canada's Hemp Industry Canadian. J Criminol Criminal Justice 57:528-554. https:// doi.org/10.3138/cjccj.2014.E11

van Dam JEG, Gorshkova TA (2003) Cell Walls and fiberslfiber formation. In: Thomas B (ed) Encyclopedia of applied plant sciences. Elsevier, Oxford, pp 87-96. https://doi.org/ 10.1016/B0-12-227050-9/00046-6

Vandepitte K et al. (2020) Hemp (Cannabis sativa L.) for highvalue textile applications: the effective long fiber yield and quality of different hemp varieties, processed using industrial flax equipment. Indust Crops Prod 158:112969. https://doi.org/10.1016/j.indcrop.2020.112969

Vantreese VL (2002) Hemp support. J Ind Hemp 7:17-31. https://doi.org/10.1300/J237v07n02_03

Vignon MR, Dupeyre D, Garcia-Jaldon C (1996) Morphological characterization of steam-exploded hemp fibers and their utilization in polypropylene-based composites. Biores Technol 58:203-215. https://doi.org/10.1016/S09608524(96)00100-9

Waldron D, Harwood J (2010) A study of the relationship between bending rigidity and the ease of decortication of flax (Linum usitattisimum) Straw. J Natural Fibers 7:42-60. https://doi.org/10.1080/15440470903579226

Wrobel-Kwiatkowska M, Starzycki M, Zebrowski J, Oszmianski J, Szopa J (2007) Lignin deficiency in transgenic flax resulted in plants with improved mechanical properties. J Biotechnol 128:919-934. https://doi.org/10.1016/j. jbiotec.2006.12.030

Yan L, Chouw N, Jayaraman K (2014) Flax fibre and its composites - A review. Compos Part B: Eng 56:296-317. https://doi.org/10.1016/j.compositesb.2013.08.014

Ying W, Di Y, Yingchao J, Qingli Z, Yu Zhihua LH, Qiuhong W (2016) Studying on plasma acid using in hemp degumming process. Functional Mater 23:496-501. https://doi.org/10. $15407 /$ fm23.03.496

Zhang J, Henriksson G, Johansson G (2000) Polygalacturonase is the key component in enzymatic retting of flax. J Biotechnol 81:85-89. https://doi.org/10.1016/S01681656(00)00286-8

Zhao D, Ji H, Du R, Wang Q, Ping W, Ge J (2020) Optimization of process conditions for microwave-assisted flax water 
retting by response surface methodology and evaluation of its fiber properties. BioResources 15:5859-5870

Zhao X, Wei X, Guo Y, Qiu C, Long S, Wang Y, Qiu H (2021) Industrial Hemp — an Old but versatile bast fiber crop. J Nat Fibers, pp 1-14. https://doi.org/10.1080/15440478.2021. 1907834

Żuk-Gołaszewska K, Gołaszewski J (2020) Hemp production. In: Crini G, Lichtfouse E (eds) Sustainable agriculture reviews 42: hemp production and applications. Springer International Publishing, Cham, pp 1-36. https://doi.org/ 10.1007/978-3-030-41384-2_1

Publisher's Note Springer Nature remains neutral with regard to jurisdictional claims in published maps and institutional affiliations. 